\title{
Communication
}

[Comunicação]

\section{Occurrence of Listeria monocytogenes in silages assessed by fluorescent in situ hybridization}

[Ocorrência de Listeria monocytogenes em silagens avaliadas por meio da hibridação in situ fluorescente]

\author{
M. Oliveira ${ }^{1}$, M. Guerra ${ }^{2}$, F. Bernardo ${ }^{1}$ \\ ${ }^{1}$ CIISA - Faculdade de Medicina Veterinária \\ Avenida da Universidade Técnica, 1300-477 \\ Lisboa, Portugal \\ ${ }^{2}$ Escola Superior de Hotelaria e Turismo do Estoril - Estoril, Portugal
}

Most domestic and wild animals are assymptomatic carriers of Listeria monocytogenes and play an important role in the dissemination of this microorganism (Sanaa et al., 1993; Bind and Delaval 1994). Animal listeriosis has a worldwide distribution, and the main source of contamination is through food (Bind and Delaval, 1994). Animals can be infected trough the consumption of several types of contaminated feed, but silages are the most frequently associated with ruminant listeriosis (Vázquez-Boland et al., 2001; Pople, 2003). The association between silage consumption and ruminant listeriosis was established for the first time in 1922 in Island (Gray, 1960). Since then, this relation has been registered in bovine and ovine (Vázquez-Boland et al., 1992; Wiedmann et al., 1999). Many cases result from the consumption of bad quality silage, subjected to inadequate fermentation, with $\mathrm{pH}$ values higher than 4.0 , which allows the multiplication of L. monocytogenes (Donald et al., 1995; Ryser et al., 1997).

The adoption of certain measures could prevent the presence of Listeria in silages: the maintenance of an anaerobic environment; the guaranty that fermentation lasts for two weeks; the use of grass with low humidity levels; the maintenance of a clean environment surrounding the silo; the elimination of silage which contacted with oxygen; and the development of rapid and reliable techniques for the detection of L. monocytogenes in these samples. The detection of $L$. monocytogenes in silages is therefore an extremely relevant procedure for the control of the sanitary safety of these products. The objectives of this study were the evaluation of the occurrence of $L$. monocytogenes in silage samples in silos produced in Portugal and the development of a fluorescent in situ hybridization (FISH) protocol for its rapid detection in these samples.

Seventy-four silage samples were collected from 37 big bale silos produced in locations from the north of Portugal: Vila Nova de Famalicão $(n=14)$, Braga $(n=10)$, Vila do Conde $(n=26)$, Cambas $(n=2)$, Póvoa do Varzim $(n=22)$. The samples were analyzed according to a microbiological protocol previously optimized for the detection of $L$. monocytogenes, based on the NF EN ISO 112901.2 standard (M.M. Guerra et al, dados não publicados).

For the FISH protocol, a specific probe for the $16 \mathrm{~S}$ rRNA of L. monocytogenes, RL-2 (5'ATAGTTTTATGGGATTAGC-3'; E. coli $168 \rightarrow 176$; Wang et al., 1991; Oliveira et al., 2003) was applied. The FISH protocol was performed as described elsewhere (Oliveira et al., 2003).

The statistical analysis of the liability of the results was performed according to the ISO/FDIS 16140:2000 (E) standard "Microbiology of food and animal feeding stuffs - protocol for the validation of alternative method".

Using the microbiological method, it was observed that $11(15.0 \%)$ silage samples were contaminated with L. monocytogenes (Table 
1).The occurrence is within the range observed by other studies in several countries (Laithier et al., 2000). Grønstøl (1979) described a much higher frequency by isolating $L$. monocytogenes in $28 \%$ of the samples studied. In Scotland, Fenlon (1986) detected L. monocytogenes in $2.5 \%$ of the samples analyzed in 1983 and in $5.9 \%$ of the samples analyzed in 1984. In the United States, Perry and Donnelly (1990) isolated L. monocytogenes in $2.9 \%$ of the silages studied.

The analysis of the silage samples by the FISH protocol revealed the presence of $L$. monocytogenes in $22(29.7 \%)$ samples (Table 1). This observation may indicate that the detection in agar plates results in a sub-estimation of the bacteria number. The difference between the results obtained by direct microscopic observation and traditional method may be related to the presence of non-viable cells, the presence of bacteria aggregates, or the selective characteristics of the agar media used, that may difficult the microorganisms multiplication (Amann et al., 1995; Auty et al., 2001).

The relative accuracy, specificity and sensitivity of the methods were determined according to the ISO/FDIS 16140:2000 (E) standard (Table 1). The FISH method presented high accuracy $(77.0 \%)$, specificity $(92.5 \%)$ and sensitivity $(72.7 \%)$. Other authors had already stated that the sensitivity of the FISH technique is higher than the one of the conventional bacteriologic methods (Auty et al., 2001).

Table 1. Occurrence of $L$. monocytogenes detection in silage samples as determined by the bacteriological and the fluorescent in situ hybridization methods and comparison between the results according to the ISO/FDIS 16140:2000(E) standard

\begin{tabular}{llc}
\hline \multicolumn{1}{c}{ Parameter } & \multicolumn{1}{c}{ Formula } & Result \\
\hline Positive agreement (PA) & Bac + and FISH + & 8 \\
Negative deviation (ND) & Bac + and FISH - & 3 \\
Positive deviation (PD) & Bac - and FISH + & 14 \\
Negative agreement (NA) & Bac - and FISH - & 49 \\
N. ${ }^{o}$ samples (N) & NA+PA+PD+ND & 74 \\
N. ${ }^{o}$ negative results (N-) & NA+PD & 53 \\
N. positive results (N+) & PA+ND & 11 \\
Relative accuracy (AC) & [(PA+NA)/N]x100\% & $77.0 \%$ \\
Relative specificity (SP) & (NA/N-)x100\% & $92.5 \%$ \\
Relative sensitivity (SE) & (PA/N+)x $100 \%$ & $72.7 \%$ \\
\hline
\end{tabular}

Legend: Bac+: positive result by the bacteriologic method; Bac-: negative result by the bacteriologic method; FISH+: positive result by the fluorescent in situ hybridization method; FISH-: negative result by the fluorescent in situ hybridization method.

The results from this study confirm the potential risk that silages represent in listeriosis transmission and suggest that the conventional bacteriologic method presents limitations for the detection of stressed microorganisms subjected to acidification, heating and dehydratation stresses during the production steps. The developed FISH methodology applied to fresh samples revealed to be adequate for the presumptive microbiological analysis of silage, being rapid, easy to perform, sensible, reproducible, and less expensive.

Keywords: silage, listeriosis, fluorescent in situ hybridization, Listeria monocytogenes, Portugal

\section{RESUMO}

Avaliou-se a qualidade microbiológica da silagem produzida em Portugal e otimizaram-se alguns aspectos relacionados com a eficácia de detecção de Listeria monocytogenes mediante protocolo baseado na técnica de hibridação in situ fluorescente (FISH) para detecção directa desse microrganismo em amostras de silagens. $O$ protocolo foi aplicado a 74 amostras, em simultâneo com o método bacteriológico convencional. Este último permitiu a detecção de L. monocytogenes em 11 silos (15\%). Por meio do protocolo FISH, observou-se que 22 silos (29,7\%) se encontravam contaminados. O método 
FISH apresentou precisão (77,0\%), especificidade (92,5\%) e sensibilidade $(72,7 \%)$ elevadas, sendo adequado para a análise microbiológica presuntiva de silagens, uma vez que é um método rápido, fácl de realizar, sensivel, reprodutível e pouco dispendioso.

Palavras-chave: silagem, listeriose, hibridação fluorescente in situ, Listeria monocytogenes

\section{ACKOWLEDGEMENTS}

The authors would like to thank to A. Fernandes, from the Direcção Regional de Agricultura de Entre Douro e Minho for the silage samples. This work was financed by Fundação para a Ciência e Tecnologia (Projects POCTI/CVT/4325272001 and POCTI/ESP/39233) and by Centro de Investigação Interdisciplinar em Sanidade Animal from the Veterinary Medicine Faculty of Lisbon (Projects 43 and 47). Manuela Oliveira has a PhD scholarship from Fundação para a Ciência e Tecnologia.

\section{REFERENCES}

AMANN, R.; LUDWIG, W.; SHLEIFER, K. Phylogenetic identification and in situ detection of individual microbial cells without cultivation. Microbiol. Rev., v.59, p.143-169, 1995.

AUTY, M.A.E.; GARDINER, G.E.; McBREARTY, S.J. et al.. Direct in situ viability assessment of bacteria in probiotic dairy products using viability staining in conjunction with confocal scanning laser microscopy. Appl. Environ. Microbiol., v.67, p.420-425, 2001.

BIND, J.L.; DELAVAL, J. Les Listerioses. Bull. Soc. Vet. Pract. France., v.78, p.387-407, 1994.

DONALD, A.S.; FENLON, D.R.; SEDDON, B. The relationship between ecophysiology, indigenous microflora and growth of Listeria monocytogenes in grass silage. $J$. Appl. Bacteriol., v.79, p.141-148, 1995.

FENLON, D.R. Rapid quantitative assessment of the distribution of Listeria in silage implicated in a suspected outbreak of listeriosis in calves. Vet. Rec., v.118, p.240-242, 1986.

GRAY, M.L. A possible link in the relationship between silage feeding and listeriosis. J. Am. Vet. Med. Assoc., v. 136, p. 205-208, 1960.

GRØNSTØL, H. Listeriosis in sheep: isolation of Listeria monocytogenes from grass silage. Acta Vet. Sci., v.20, p.492497, 1979 .
LAITHIER, C.; HEUCHEL, V.; CORROT, G. et al. La contamination des fourrages par Listeria monocytogenes: synthèse des connaissances. In: $7^{\mathrm{e}}$ RENCONTRE RECHERCHES RUMINANTS, 7., Paris, France, 2000. p.347.

OLIVEIRA, M.; ANDRADE, G.; GUERRA, M. et al. Development of a Fluorescent in situ Hybridization protocol for the rapid detection and enumeration of Listeria monocytogenes in milk. Rev. Port. Cienc. Vet., v.98, p.119124, 2003.

PERRY, C.M.; DONNELLY, C.W. Incidence of Listeria monocytogenes in silage and its subsequent control by specific and nonspecific antagonism. J. Food Protec., v.53, p.642-647, 1990.

POPLE, N. Diagnoses in bovine abortions. Anim. Health Expos., v.5, p.1-2, 2003.

RYSER, E.T.; ARIMI, S.M.; DONNELLY, C.W. Effects of $\mathrm{pH}$ on distribution of Listeria ribotypes in corn, hay and grass silage. Appl. Environ. Microbiol., v.63, p.3695-3697, 1997.

SANAA, M.; POUTREL, B.; MENARD, J.L. et al. Risk factors associated with contamination of raw milk by Listeria monocytogenes in dairy farms. J. Dairy Sci., v.76, p.28912898, 1993.

VÁZQUEZ-BOLAND, J.A.; DOMINGUEZ, L.; BLANCO, $M$. et al. Epidemiologic investigation of a silage-associated epizootic of ovine listeric encephalites, using a new Listeriaselective enumeration medium and phage typing. Am. J. Vet. Res., v.53, p.368-371, 1992.

VÁZQUEZ-BOLAND, J. A.; KUHN, M.; BERCHE, P. et al. Listeria pathogenesis and molecular virulence determinants. Clin. Microbiol. Rev., v.14, p.584-640, 2001.

WANG, R. -F.; CAO, W.-W.; JOHNSON, M. G. Development of a 16S rRNA-based oligomer probe specific for Listeria monocytogenes. Appl. Environ. Microbiol., v.57, p.3666-3670, 1991.

WIEDMANN, M.; MOBINI, S.; COLE Jr., R.J et al. Molecular investigation of a listeriosis outbreak in goats caused by an unusual strain of Listeria monocytogenes. $J$. Am. Vet. Med. Assoc., v.215, p.369-371, 1999. 